\title{
Avrupa'da Sosyal Güvenlik Sisteminin Finansmanı: Farklı Refah Devletleri Üzerine Bir İnceleme
}

\author{
Zeynep Özmen*
}

Düzce Üniversitesi, Gümüşova Meslek Yüksek Okulu, Düzce.

\section{$\ddot{O} z$}

Avrupa'da sosyal güvenlik sisteminin finansmanı ülkeden ülkeye farklhliklar göstermekte ve bu farklılıklar ülkelerin refah modelleri ile de bağlantılandırılmaktadır. Sosyal güvenliğin finansmanında iki temel sistem bulunmaktadır: Vergiye (Beveridge modeli) ve prime dayal (Bismarck modeli) sistemler. Avrupa'da sosyal geleneklere bağh olarak farklı modeller varlığını sürdürmekle birlikte, son yillarda iki sistemin birbirine yaklaştığl, karma bir sistem oluştuğu gözlenmektedir. Çalışmada, öncelikle Bismarck, Beveridge ve Karma modelden bahsedilmiş, daha sonra da refah modelleri sağlık sistemleri açısından açıklanmıştır. Gelişmiş ülkeler, sosyal refah hizmetleri açısından, belirli nitelik ve kriterlere göre sınflandırılmış ve farklı refah devleti kategorilerine ayrılmıştır. Bu konuda literatürde yer alan önemli çalışmalardan biri, Esping Andersen'in refah modeli ayrumıdır. Esping-Andersen, refah modellerini; liberal refah modeli, muhafazakar refah modeli ve sosyal-demokrat refah modeli olarak sinıflandırmıştır. Leibried ise, refah kapitalizminin üç dünyası adını verdiği çerçeveye, bir dördüncü dünya olarak Güney Avrupa Modelini eklemiştir. Çalışmanın amacı farklı refah devletlerinde uygulanan sosyal güvenlik sistemlerinin finansmanına ilişkin politikalara değinilerek, refah modelleri içinde Türkiye'nin yerinin belirlenmesi ve belirlenen model çerçevesinde elde edilen deneyimlerle Türkiye'deki sosyal güvenlik sisteminin geleceğine ışık tutulmak istenmesidir.

Anahtar Kelimeler: Sosyal Güvenlik, Refah Devleti, Sosyal Güvenliğin Finansmanı.

\section{Financing of Social Security in Europe: A Research on Different Welfare States}

\begin{abstract}
In Europe, the financing of the social security system varies from country to country, and these differences are linked to countries' welfare models. There are two basic systems for financing social security: the tax system (Beveridge model) and the prime based (Bismarck model) systems. It is observed that in recent years, there has been a mixed system of two systems approaching each other, while maintaining the existence of different models depending on social traditions in Europe. In the study, firstly Bismarck, Beveridge and Karma models were mentioned, then welfare models were explained in terms of health systems. Developed countries are classified according to specific qualities and criteria in terms of social welfare services and are divided into different welfare state categories. One of the important studies in the literature in this regard is Esping Andersen's welfare model. Esping-Andersen, prosperity models; The liberal welfare model, the conservative welfare model and the social-democratic welfare model. Leibried has added the Southern European Model as a fourth world, the framework that gave the name of the three worlds of prosperous capitalism. The purpose of the study is to address the policy of financing the social security systems applied in different welfare states and to shed light on the future of the social security system in Turkey with the experience gained in determining the location of Turkey within the welfare models and within the framework of the determined model.
\end{abstract}

Keywords: Social Security, Welfare State, Financing of Social Security. 


\section{GİRIŞ}

Bir ülkenin gelişme seviyesi hakkında, sosyal güvenlik çok önemli ipuçları vermektedir. Sosyal güvenlik sistemimizin etkinliğinin ve verimliliğinin artırılması yönünde günümüze kadar bir dizi çalışmalar yapılmış, ancak sosyal güvenlik kurumlarımızın değişen çağ ve insan ihtiyaçlarıyla paralellik gösterebilecek, ihtiyaçlara cevap verebilecek düzeye erişmesi sağlanamamıştır.

Sosyal güvenliğin gelir kaynakları, genel olarak birbirinden kesin çizgilerle ayrılan iki temel düşünceden hareketle belirlenir. Bunlardan ilki, sosyal güvenliği, toplumun bir sorunu olarak görmekte ve bireyin sosyal güvenliğini sağlama sorumluluğunu devlete yüklemektedir. Kişinin sosyal güvenliği, toplumun bir yurttaşı olmaktan doğan bir hak niteliğini taşır. Bu bağlamda, sosyal güvenliğin tüm giderleri devlet tarafından karşılanacak, giderek ulusal bütçeden yapılacak katkılar ile vergiler, sosyal güvenliğin finansman kaynağını oluşturacaktır. İkinci düşünce ise, sosyal güvenliği, her şeyden önce kişiye ve kişisel sorumluluk bilincine dayanır. Kişisel sorumluluk ön plana çıkınca, kişi kendisinin ve ailesinin ekonomik güvencesini devletten önce düşünmek zorundadır. Bunun doğal sonucu ise, sosyal güvenliğin finansman kaynağının işçi ve işverenlerden alınan primlerle karşılanmasıdır (Güzel vd:53).

Türkiye ve $A B^{\prime}$ de sosyal güvenlik sistemlerinin eşgüdümü kapsamında farklı uygulamalar söz konusu olabilmektedir. $\mathrm{AB}^{\prime}$ de sosyal güvenlik sistemleri, Üye ülkelerin yetki alanına girmekte olup, $\mathrm{AB}$ seviyesinde kapsamlı bir sosyal güvenlik mevzuatının varlığından söz etmek mümkün değildir. Ancak Birlik, kişilerin serbest dolaşımının önündeki engellerin kaldırılması ve Tek Pazarın etkin işleyişinin sağlanması amacıyla, üye ülke sosyal güvenlik mevzuatlarının koordinasyonunu sağlamayı hedeflemiştir. Ülkemizde de, AB'ne giriş aşamasında kademeli bir geçiş dönemi ile reform niteliğindeki "Tek Çatı" kavramı, siyasi olgu, kurumsal bütünleşme ve sonuçta gerçek bir sosyal güvenlik anlayışını gerçekleştirecek şekilde düzenlemeler bulunmaktadır.

Çalışmada, dünyada uygulanan sosyal güvenlik sistemlerinin finansman modellerinden bahsedilmiş daha sonra refah devleti ile ilgili açıklamalara yer verilmiş, refah devletlerinin sınıflandırılmasına yönelik literatür çalışması yapılmış ve gelişmiş ülkeler sosyal güvenlik sistemlerinin finansmanlarına göre gruplandırılmıştır. Refah rejimlerinin sınıflandırılmasına ilişkin literatürde birçok çalışma olmasına rağmen, bu araştırmada Esping-Andersen refah modeli ve Leibfried'in Refah modeli irdelenmiştir. Bu çerçevede, uygulamada ortaya çıkan farklı refah devleti modelleri, izledikleri refah politikaları analiz edilerek sosyal güvenlik finansmanlarına göre incelemeye tabi tutulmuştur.

Refah rejimi sınıflandırma çalışmalarına göre Türkiye Güney Avrupa refah rejimi grubuna benzer özellikler göstermektedir. Son yıllarda hem Güney Avrupa sosyal güvenlik sisteminde hem de Türkiye'nin sosyal güvenlik sisteminde önemli bir dönüşüm yaşanmaktadır. Bu çalışma ile refah devleti çerçevesinde gelişmiş ülkelerin 
sosyal güvenlik sistemi finansman uygulamaları değerlendirilerek Türkiye'deki sosyal güvenlik sistemine bir katkı taşıması amaçlanmıştır.

\section{SOSYAL GÜVENLİĞIN FİNANSMANI VE FINANSMANI ETKILEYEN MODELLER}

Sosyal sigorta modelinin uygulandığı ülkelerde sosyal güvenlik sistemlerinin başlıca gelir kaynağı̆, işçi ve işverenlerden alınan ve genellikle "prim" olarak adlandırılan paralardan oluşmaktadır. (Güzel vd., 2014: 76).

İşçi ve işverenlerin ödeyecekleri primler, işçinin (sigortalının) emek geliri esas alınarak, belirli oranlar dahilinde saptanır. Günümüzde genellikle işverenlerin ödedikleri prim oran ve miktarı, işçilerinkinden daha yüksektir; hatta kimi sigorta kolları için sadece işverenler prim öderler. Örneğin, öteki ülkelerde olduğu gibi, ülkemizde de iş kazaları ve meslek hastalıkları ile analık sigortaları primlerinin tümü işverenlerce ödenir (Talas, 1992: 357).

İşçi ve işverenler yanında, devletin de sosyal güvenliğin finansmanına katkısı genel bir kural haline gelmiş, hatta devlet katkısı gittikçe artma eğilimi göstermiştir. Devletin, sosyal güvenliğin finansmanına katkısı; primlere benzer biçimde ödemelerde bulunarak; sağlanan sosyal gelirlerle ilgili ödemelere katılarak, sosyal güvenlik kurumlarının yönetim giderlerini karşılayarak, anılan kurumların bilanço açı̆̆ını kapatarak, vergi indirimi ve başka kolaylıklar tanıma gibi yöntemlerle söz konusu olabilmektedir (Dilik, 1991: 235).

Vergi tekniği de, sosyal güvenliğin finansman kaynağı olarak, tarihsel gelişim içinde, kimi ülkelerde önemli bir yer tutmuştur. Sözgelimi, Yeni Zelanda'da sosyal güvenlik sisteminin oluşturulduğu 1938 yılından itibaren ve son yıllara kadar gelirler üzerinden alınan vergiler, sistemin tek finansman kaynağı olmuştur. İngiltere'de Beveridge Raporu, kimi riskler açısından aynı ilkeyi benimsemiştir. Bu rapora göre aile yükleri ile ulusal sağlık sigortasının finansmanı, ulusal dayanışma ilkesi çerçevesinde vergilerle sağlanmalıdır. İngiltere'de son yıllara değin bu uygulama devam etmiştir. Danimarka, ulusal bütçeden (toplanan vergilerden) sosyal güvenliğin finansmanı ilkesine bağlı kalmıştır. Hollanda'da ise, meslek gelirleri üzerinden alınan dolaysız vergiler, sosyal güvenliğin finansman kaynağını oluşturmaktadır. Öteki AB ülkelerinde, vergi tekniğine, istinaen ve daha çok dolaylı vergiler çerçevesinde başvurulmaktadır. Oysa Norveç 'de sosyal güvenliğin finansmanı açısından vergiler önemli bir yer tutar.

\subsection{Bismarck Modeli}

Sosyal sigorta tekniği, bir sosyal güvenlik tekniği olarak öncelikle sanayileşme süreci içerisine işçi kesiminin korunmasını sağlamak amacıyla bulunmuştur. Sosyal sigorta sistemi 1883-1889 yılları arasında ilk olarak Bismarck'ın başbakanlığındaki Alman imparatorluğu hükümeti tarafından kurulmuştur (Korkusuz ve Uğur, 2010: 69).

Bismarck'ın sosyal güvenlik politikası kurmasındaki amaç, gelişen sosyalist akımlara karşı, bir yandan geleneksel yöntemlerle mücadele etmek ve öbür taraftan 
da sosyal politika alanında reform hareketlerine girişerek, sosyalistlerin etkisini kırmak olmuştur.

Sistem başlangıçta belirli bir miktar ücretin altında kalan sanayi işçilerini kapsamış, sonradan diğer ücretlilere doğru genişletilmiştir. Sistem tamamen özel sigorta ilkesini benimsemiş olmakla beraber, sisteme girmeyi zorunlu görmüştür (Günay, 2004:554). 1883 tarihli hastalık sigortası, 1884 yılında kabul edilen, iş kazası sigortası ve 1889 tarihli sakatlık ve yaşlılık sigortaları kabul edilmiştir (Korkusuz ve Uğur, 2010: 69).

\subsection{Beveridge Modeli}

$\mathrm{Bu}$ modelde sosyal güvenlik sistemin ana ilkeleri şu başlıklar altında toplanmiştır (Arıcı, 2015: 17).

1. Genellik ve Sigorta Yardımlarında Teklik İlkesi: Sadece işçiler değil, tüm İngiliz halk1, mesleki faaliyetleri ne olursa olsun, toplumun bir bireyi olma sıfatıla, sosyal güvenlik kapsamına alınmalıdır.

2. Yönetimde Birlik İlkesi: Raporda yer alan bu ilke ile dağınık halde bulunan tüm sosyal sigorta kurumlarını birleştirmeyi amaçlayan bir ilkedir.

3. Primlerde Teklik ve Vergilerle Katkı Sağlama İlkesi: Rapor, kural olarak kişisel sorumluluk ilkesini benimsemişti. Başka deyişle, devletin yanında, bireylerin de sosyal güvenliğin finansmanına katkıda bulunmaları gerekir.

4. Sosyal Güvenlik Sisteminin "tam istihdam" ve "ulusal sağlık" Politikalarıyla Desteklenmesi: Rapora göre, sigorta yardımlarının dağıtımıyla ilgili olarak oluşturulacak kamu hizmeti, daha genel bir sistemin yalnızca belirli bir parçasını oluştur. Bunun etkin olabilmesi için, öteki politikalarla desteklenmesi kaçınılmazdır. Ekonomik planda tam istihdam politikası ulusal sağlık hizmeti biçiminde somutlaştırılabilecek genel bir sağlık politikası, sosyal güvenlik istemini tamamlayan politikalar olmalıdır. Ulusal sağlık hizmetinin finansmanı vergilerle sağlanmalı, böylece tüm halk tıbbi yardımlardan ücretsiz olarak yararlandırılmalıdır.

\subsection{Karma Model}

Bismarck tarafından kurulan ve ilk modern sosyal güvenlik sistemi olan İşçi sigortası Modeli ile Beveridge tarafından kurulan Halk Sigortası modeli pek çok ülkede benimsenmiş, bazı ülkeler ise her iki sistemi birlikte uygulama çabasına girmiştir. İşçi Sigortası Modeli ile Halk Sigortası Modeli'nin birlikte uygulanması sonucu ortaya çıkan ve Karma Model olarak bilinen sosyal güvenlik sisteminde finansman, işçi ücretlerinin belirli bir yüzdesi üzerinden işverenleri tarafından sağlanmaktadır. Hollanda'da uygulanan söz konusu modelin karakteristiklerinin arasında; mesleki risk yerine sosyal riski vurgulayan evrensel düzenlemeler ve yüksek fayda düzeyleri, sosyal güvenlik yönetimini ve sosyo-ekonomik politika yapıcıları kapsayan bir organizasyon, gelir telafisine odaklanma, kadının işgücüne düşük düzeyde katılımı gibi unsurlar yer almaktadır (Jackson, 2006: 12). 


\section{REFAH REJIMLERİ AÇISINDAN SOSYAL GÜVENLIK SİSTEMLERINIIN FINANSMANI}

Refah devleti en genel haliyle, bireylere temel veya normal seviyede refah veya refah imkânı sağlayan devlet olarak tanımlanabilir. Refah devleti, bireyin yaşamının tüm yönleri ile ilgilenen, bireylere ekonomik ve sosyal imkânlara ulaşmada eşit şans tanıyan, vatandaşlarına asgari bir yaşam standardını sağlayan devleti ifade etmektedir (Seyidoğlu, 1999: 497). Modern anlamda refah devletinin temelleri, 19. yüzyılın ortalarında İngiltere'de temel eğitimi sağlamak amaciyla düzenlenen yasal düzenlemeye kadar götürülmektedir (Luhmann, 2002: 5). Modern refah devleti için kabul edilen bir diğer başlangıç noktası ise, ilk defa 1883'te Bismarck tarafından getirilen sosyal sigorta uygulamasıdır. Bunlardan önce de, yoksullara yönelik birtakım yasalar söz konusudur; ancak bunlar genelde refah devleti için bir başlangıç kabul edilmemektedir (Pierson, 1998: 16).

Asa Briggs' in (2000: 16) meşhur tanımına göre, refah devleti, piyasa güçlerini üç boyutta yönlendirebilmek adına siyaset ve yönetimin etkin bir şekilde kullanıldığı örgütlü bir güçtür. İlk olarak, refah devleti bireylerin ve ailelerin yaptıkları işlerin veya varlıklarının piyasa değerinden bağımsız olarak, minimum düzeyde bir geliri garanti eder. İkinci olarak, bireylerin ve ailelerin karşılaşabilecekleri sosyal riskleri (hastalık, yaşlılık ve işsizlik gibi) azaltarak belli bir ölçüde güvence sağlar ve böylelikle bireysel veya ailevi krizlerin önüne geçer. Üçüncü ve son olarak da bütün bireylere, statü veya sınıf ayrımı gözetmeksizin genel kabul görmüş sosyal hizmetler çerçevesinde en iyi standartları sağlar.

Esping-Andersen'e (1990: 14) göre de günümüzde refah devleti endüstriyel gelişimin pasif bir yan ürünü olmayıp kurumsallaşmasıyla birlikte, geleceği ciddi biçimde şekillendiren güçlü bir sosyal mekanizma haline gelmiştir.

Refah devleti sistemlerinin sınıflandırılmasına ilişkin olarak, bilim adamı ve araştırmacılar tarafından en çok benimsenen tasnif, Esping-Andersen'in sınıflandırmasıdır. Esping-Andersen, kitabında 3 tür refah rejimi ayrımı yapmaktadır. Liberal refah modeli (ABD, İngiltere), Muhafazakâr veya Kıta Avrupası refah modeli (Fransa, Almanya, Belçika) ve sosyal-demokratik veya İskandinav refah modeli (İsveç, Danimarka) dir. (Sözer, 1994: 16).

Leibried'e göre ise, kapsam bakımından refah devletleri, riskler ve gruplar bakımından kategorik veya evrensel olma kıstasına göre dört tipe ayrılabilir:

1. Parçalanmış refah devleti; bazı riskleri bazı gruplar için kategorik şekilde kapsar,

2. Kısmi refah devleti; bazı riskleri grupların önemli çoğunluğu için evrensel denilebilecek boyutta kapsar,

3. Bölünmüş refah devleti; risklerin büyük çoğunluğunu bazı gruplar için grubun tümünü içerecek şekilde kapsar, 
4. Kapsamlı refah devleti; risklerin büyük çoğunluğunu neredeyse bütün gruplar için kapsar ve evrensellik kıstası geçerlidir.

Bu modellerden sadece kapsamlı olan refah devleti modeli evrensellik özelliği dolayısıyla sosyal devlet olarak nitelendirilebilecek bir tür olarak değerlendirilmiştir.

Tablo 1. Esping Andersen'in Refah Devleti Sınırlandırması

\begin{tabular}{|c|c|c|}
\hline Liberal & Muhafazakâr & Sosyal Demokrat \\
\hline ABD & Almanya & İsveç \\
\hline İsviçre & Fransa & Norveç \\
\hline Japonya & İtalya & Danimarka \\
\hline Kanada & Avusturya & Finlandiya \\
\hline Avustralya & Belçika & Hollanda \\
\hline
\end{tabular}

Kaynak: Esping-Andersen, G. (1990). The Three Worlds of Welfare Capitalism, UK: Polity Press, 74 .

Bunun yanında Leibried, sosyal politika rejimleri temelinde sinıflandırdığ refah devleti tiplerini ise; Modern Refah Devleti-İskandinavya modeli, Kurumsal Refah Modeli-Bismark Modeli, Kalıntı Refah Devleti Anglo-Sakson Modeli ve Tam Oluşmamış Refah Devleti-Latin Havzası Modeli olmak üzere dört ayrı grupta toplamıştır (Leibfried, 1993: 133).

Ferrera (1996: 20) da Leibfried gibi Güney Avrupa ülkelerinin ayrı bir refah rejimine sahip olduğunu öne sürmüş ve bu rejimi Güney Avrupa Modeli (Southern Model) olarak isimlendirmiştir. Ferrera'ya göre bu sınıfı oluşturan Yunanistan, İtalya, Portekiz ve İspanya'nın kendine has özellikleri bulunmaktadır. Bu ülkelerin işgücü piyasası, Kıta Avrupası Refah Rejimi 'ne göre radikal biçimde farklıdır ve güçlü bir tarımsal yönelim gösterir. Ayrıca, İskandinav ülkelerinin aksine bu ülkelerde tam istihdam geleneği bulunmamaktadır.

Türk refah rejimi ile ilgili yapılan çalışmalarda Türkiye de Güney Avrupa refah rejimi içerisinde sınıflandırılmış ve bu devletlerin refah özellikleri bağlamında ele alınmaktadır (Buğra ve Keyder, 2006:217). Güney Avrupa modeli Türk refah sistemini tartışmak adına çok kullanışlı bir analitik bakış açısını temsil eder. Güney Avrupa refah rejimlerinde kamu hizmetleri, sosyal sigorta ve emeklilik ödenekleri yüksek oranda sunulmaktadır. Diğer taraftan söz konusu refah rejimin de sosyal güvenliğin geri kaldığı noktalarda sosyal riskler aile kurumu tarafından karşılanmaktadır. Ayrıca bu refah rejiminde sosyal refah sağlayan kurumlar parçalı bir yapıda ve devletin ağırlığı ekonomik ve sosyal hayatın her noktasında görülebilmektedir.

Güney Avrupa modelinde yüksek bir enformel sektör ile, kendi hesabına çalışanların sayısı kutuplaşmanın varlığına işarettir. Yasadışı faaliyetler, beyan dışı faaliyetler ve enformel ekonomi şeklinde tasnif edilen kayıt dışı ekonominin Türkiye'deki boyutları, kutuplaşma için güzel bir örnektir. 2010 yılında 31 Avrupa ülkesini kapsayan araştırmaya göre, Türkiye kayıt dış1lıta \%33,5 oranla 4. Sırada yer almaktadır (Önder, 2012: 55). 


\section{SEÇILMIŞ BAZI ÜLKELERDE SOSYAL GÜVENLIK SISTEMININ FINANSMANI}

\subsection{Almanya}

1881'de Bismark tarafından temeli atılan Bismark sistemi Fransa, Almanya ve Türkiye'de geçerli olan bir sistemdir. Sistemin özü, çalışma esasına dayalı sosyal sigorta mekanizmasına dayanıyor olmasıdır. Bireyler, bir işi yapmaları halinde sosyal hukuk bakımından güvence kapsamına alınmaktadır. Sistemin finansmanı, yararlananların ödedikleri sigorta primleriyle karşılanmaktadır. Yani yalnızca prim ödeyenin ivaza hak kazandığı bu duruma "karşıllklılık ilkesi" (reciprocity) ismi verilmektedir. Bundan dolayı, sosyal güvenlik açısından tüm nüfusun kapsam içine alınması gerçekleşemeyebilir (Özdemir, 2004:590).

Almanya'da uzun vadeli sigorta kolları, "kuşaklararası dağıtım modeli”ne göre (pay as-you-go) ve zorunlu bir sosyal sigorta programı olarak devlet tarafindan yürütülmektedir. Bunun yanında, zorunlu devlet sigortasını tamamlayıcı nitelikte, gönüllülük esasına dayanan ve şirket temelli ikinci sütun emeklilik sistemleri ve üçüncü sütun bireysel emeklilik sistemleri mevcuttur.

Uzun vadeli sigorta kollarından yapılan yardımların finansmanı, sigortalılardan, kendi adına ve hesabına bağımsız çalışanlardan ve işverenlerden alınan prim kesintileriyle sağlanmaktadır. Sigortalılarda prim kesintileri, aylık maaşlarının \%9,95'i oranındayken, geliri 400 avronun altında olanlardan bu kesinti yapilmamakta ve 401 ila 800 avro arasinda olanlardan ise indirimli olarak alınmaktadır. İşveren payı, aylık bordronun \%9,95'idir. Bu oran, 400 avrodan düşük gelirle çalıştırılan işçiler için \%15; maden ocakları, demiryolları ve deniz işletmelerinde $\% 16,45$ olarak uygulanmaktadır. Öte yandan, kendi adına ve hesabına bağımsız çalışanlardan aylık gelirlerinin \%19,9'u oranında prim kesintisi yapılmaktadır. Devlet ise sigorta temelli olmayan yardımları finanse etmekte, buna ek olarak, sigorta temelli yardımlar için de katkı sağlamaktadır ve çocuk yetiştirme dönemleri için primleri ödemektedir. Böylece, zorunlu emeklilik sigortasının toplam harcamalarının \%31'i devletçe finanse edilmiş olmaktadır. Primler hastalık kasaları tarafından toplanıp, emeklilik sigortası kurumlarına aktarılmaktadır (SGK, 2012:45).

Sistemin finansmanına bakıldığında; Sigortalı: Kazancının \%9,75; eğer aylık kazancı aylık $400 €^{\prime}$ dan düşükse, prim alınmaz (gönüllü olarak bağışta bulunulabilir); aylık kazanç $401 €$ ve $800 €$ arasında olanlar için azalan oranlı prim alınır. Serbest Çalışan: Kazancının \%19,5'idir. İşveren: Ücretin \%9,75'i; aylık kazancın $400 €$ altında olan işverenler için kazancın \%12'si, Alman Emeklilik Sigortasına tabi olan madenciler, demiryolu işçileri ve denizcilerin işverenleri için ücretin \%16.5'idir. Devlet: Primler ile karşılanamayan sigorta hizmeti maliyetlerini sübvanse eder.

Almanya'da ortalama hayat süresinin yükselmesi ve doğum hızındaki düşmeye bağlı olarak genç nüfus oranının azalması karşısında nüfus giderek yaşlanmaktadır. Toplam nüfus içinde yer alan yaşlıların sağlık ve bakım hizmetleri gibi sosyal 
hizmetler üzerinde diğer yaş gruplarına kıyasla daha fazla talep baskısı yaptığı bilinmektedir.

Dolayısıyla, Almanya giderek yaşlanmakta olan nüfusu için daha fazla kaynak tahsis etmek sorunu ile karşı karşıya gelmektedir. Büyük aile tipinin hemen hemen yok olması karşısında yaşlıların bakımı aile ortamı içinde gittikçe azaldığından geleneksel toplumlardan farklı olarak yaşlıların bakımı ev dışında değişik huzur ve yaşlı bakım evlerinde görülmektedir. Bu gidişatı frenlemek ve kurumsal bakım hizmetlerinin maliyetini düşürmek amacıyla bakıma muhtaç yaşlıların evde dolayısıyla aile ortamında bakılması için sosyal alanda birçok reform niteliğinde yeniliklere gidilmiştir (Saltman vd., 2004: 65).

Yaşlılık sorununun dişında yine demografik değişimin bir sonucu olarak Almanya'nın karşı karşıya geldiği bir diğer önemli gelişme ise Alman nüfusunun gittikçe azalmasıdır. Buna karşılık bir dizi yeni tedbirlerin alındığını söyleyebiliriz. Her ne kadar bu tedbirlerin çocukların aile için iktisadi bir yük olmaması için sosyoekonomik türden olduğu iddia edilebilirse de 'çocuk bakım parası' uygulamalarında görüldüğü gibi bunların daha doğurganlık hızını artırıcı politikalar olduğunu vurgulayabiliriz. Sosyal güvenlik alanında resmen 'aile politikası' diye adlandırılan fakat mahiyeti itibariyle 'nüfus politikası' olan bu programlar çerçevesinde çocuklu ailelere 1992 yılından beri her yıl ortalama olarak 130 milyar $€$ dolayli-dolaysız olarak transfer edilmektedir (Saltman vd., 2004: 67).

Geleneksel Alman sosyal sigorta modelinden giderek uzaklaşılmasına neden olan bu tablonun gerisinde, Doğu ve Batı Almanya'nın birleşmesinden ardından iç talep ve ücretlerde görülen enflasyonist yükseliş ve 2005 yılına kadar süregelen sıkıntılı ekonomik süreç belirleyici olmuştur. Öyle ki 1995-2004 yılları arasında Almanya'nın GSYİH büyümesi on beş Avrupa Birliği üyesi ülke arasında en düşüklerden birisi olarak seyretmiştir. Bu kötü gidiş özellikle 2001-2005 yılları arasında hükümet üzerinde baskı oluşturmuş, ekonominin gelişmesini ve istihdamın artmasını sağlamak için gereken yapısal koşulları geliştirmeyi amaçlayan 'Agenda 2010' adlı bir reform girişimi başlatılmıştır. Reform paketi, başta sağlık sigortası olmak üzere, sosyal güvenlik sistemi ve ücret dişı emek maliyetlerinin azaltılması ve işsizlik sigortasına hak kazanma koşullarının zorlaştırılması gibi tedbirleri içermektedir (SGK, 2012:178).

\section{2. İngiltere}

Beveridge sistemi üç amaçlı bir sosyal devlet politikası önerir: Bunlar tüm İngiltere vatandaşlarının sosyal güvelik kapsamına alınması, Ulusal Sağlık Hizmeti ağının oluşturulması ve tam istihdamın sağlanmasıdır. Bu sistem zamanında Sovyet finansman sistemini örnek aldığ için, bu sistemin sadece vergilerle finanse edilmesi, ek olarak prim toplanmaması önerileri arasında yer almaktadır (Özmen, 2015: 126).

İngiltere sosyal güvenlik sistemi genel olarak katılmalı sosyal güvenlik esasına dayanır. Hizmetler Ulusal Sağlık Servisi tarafından sağlanır. Bu servis vergiler ve bir miktar da primler vasıtasıyla finansmanını sağlar. Birleşik Krallık Sosyal Güvenlik 
Mevzuatı genel olarak 1975 yılında çıkartılan Sosyal Güvenlik Kanunu içinde toplanmıştır.

İngiltere'de ekonomide devletin rolünü azaltmanın bir sonucu olarak emeklilik programı reforma tabi tutulmuştur. 1979'dan 1997'ye kadar iktidarda kalan Muhafazakar Hükümet sendikaların gücünü azaltmış, kamu harcamalarını sınırlamış, refah programlarını daraltmış ve emek piyasasını daha esnek bir hale getirmiştir. Hükümet 1985 ve 1986 yıllarında sosyal güvenlik sisteminde bazı değişikliklere gitmiştir. Bunlardan en önemlisi, 1986'da yapılan ve çalışanları kamu emeklilik sisteminden özel emeklilik sistemine geçişine olanak veren düzenlemedir. Aynı yıl, ödeme ve endeksleme kurallarında değişikliğe gidilmiş ve özellikle yararlanma olanakları dikkati çekici şekilde daraltılmıştır (Glennerster, 2000: 134).

1997 Mart'inda Başbakan J. Major, sosyal güvenlik sistemi ile ilgili olarak "birkaç nesil sonra kamu emeklilik sisteminin birçok insan için terk edilmiş olacağını" ifade etmiştir. Diğer bir ifade ile "bugünün çocukları emeklilik yaşına geldiklerinde artık devlet emeklilik sisteminden yararlanamayacaklardır". Major'un bu yaklaşımı kamu emeklilik sistemi yerini alacak zorunlu fakat özel kurumlarca karşılanan bir emeklilik sisteminin ilk işaretlerini vermektedir. Halen çalışanlar bundan etkilenmeyecek, fakat bu planın kabulünden sonra istihdama katılacak her şahıs emekliliğini bir sigorta şirketinden veya özel bir şirket tarafından yönetilen fonlardan alacaktır.

Aslında diğer endüstri ülkeleri ile mukayese edildiğinde İngiliz emeklilik sisteminin en dikkat çekici özelliği, sosyal güvenlik giderlerinin kamu harcamaları içinde düşük düzeyde kalmasıdır. Yapılan hesaplamalara göre, 2050'lere kadar kamu emeklilik harcamaları ve gelirleri arasındaki değer farkı GSMH'nın sadece \%4.6' sına varacaktır. Bu oran ABD'deki \%26, Fransa, Almanya ve Japonya'daki \%100'ün üzerindeki değerlerle mukayese edildiğinde çok düşük kalmaktadır. Bu durumun yaratılmasında, sosyal güvenlik harcamalarında sınırlanmaya gidilmesinin önemli rolü olmuştur. Böylece İngiltere uzun dönemli mali krizlerden uzak kalabilmiştir. 1995 yılında yapılan hesaplamalara göre, 2030 yılında İngiltere'de genel olarak hükümetin sosyal güvenlik alanındaki mali yükümlülükleri eksi olacaktır. Buna karşılık, aynı dönemde Japonya'da bu yükümlülük, GSMH'nın \%300'ünden, ABD, Fransa ve Almanya'da \%100' den fazla olacaktır.

$\mathrm{Bu}$ sonuç büyük ölçüde demografik gelişmelerden de kaynaklanmaktadır. İngiltere'de, nüfus diğer ülkelere nazaran daha yavaş yaşlanacaktır. Çok daha önemli olarak bu ülkede kamu emeklilik ödemelerinin gerçek değerini koruduğu gözlenmektedir. Ayrıca, hükümet "ilave" emeklilikten doğan maliyetleri önemli ölçüde azaltmaktadır. Çünkü, yararlanma koşullarının zorlaştırılması, çalışanları geleneksel programları terk etmeye ve özel düzenlenmelere yönelmeye zorlamaktadır. İngiliz sistemini Kara Avrupası ülkelerinden ayıran bir diğer önemli fark ise, "mesleki emeklilik" yükümlülüklerinin hali hazırda fona bağlanmasıdır. İngiltere'de özel sektör emeklilik fonları 600 Milyar Sterlin düzeyindedir. Bu rakam tüm AB fonlarından daha 
büyüktür. Aslında bu ülkede mevcut sistemin tatmin edici olduğunu söylemek oldukça zordur (Hayek, 2000: 156).

Genel olarak ifade etmek gerekirse İngiliz sistemi primli ve devlet katkısının ağırlıklı olduğu bir yapı arz etmektedir. Aynı zamanda sistemde geliri düşük olanları kapsayan refah ödemeleri de mevcuttur. Çalışanlar için sağlanan "ikincil emeklilik ödemeleri" (second-tier pension) ise, ya "devlet, gelirlerle ilişkili emeklilik planları" (state earnings-related pension shame-SERPS) veya "mesleki veya özel emeklilik planları"ndan karşılanmaktadır (Campbell, 2000: 101).

Son yıllarda Birleşik Krallık ekonomisinin karşılaştı̆̆ı güçlükler etkisini sosyal güvenlik mevzuatında da göstermiş ve 1995 ve 1999'da çıkarılan yasalarla sosyal güvenlik yardımları sadece en muhtaç kişilere yönelmiş, kişisel özel sigortalar ve işyeri sosyal güvenlik programları teşvik edilmiş, sosyal güvenlik giderleri, kira, çocuk, işsizlik, hastalık yardımlarının miktarları indirilmiştir. Fakat özürlülere yapılan yardımlara dokunulmamıştır. 1994 tarihli Yasal Hastalık Yardımı Kanunu hastalık ve iş kazası primlerinin yükünü önemli ölçüde devletten alıp işverenlere yüklemiştir. 1995 tarihinde yapılan değişiklikle de hastalık ve sakatlık sigortaları birleştirilerek iş göremezlik yardımı adını almıştır. 1998 ve 2000 yıllarında yapılan değişikliklerle sosyal güvenlik yardımları ülkedeki vergi sistemi ile daha yakından ilgilendirilerek birçok kamu yardımı (katılmasız rejim) vergi kredisi olarak adlandırıldı. Ayrıca sosyal güvenlik kurumunun birçok görevi Ulusal Vergi Kurumuna devredildi. 1998 sayılı Kanunla sosyal güvenlik fonlarının nasıl ve nerelere ödeneceğine ilişkin kararları alma yetkisi sosyal güvenlik işlerinden sorumlu Devlet Bakanlığına bırakıldı (Tuncay ve Ekmekçi, 2012:30).

2013 yılı itibariyle finansman katkılarına baktığımızda sigortalılar haftalık kazançlarının \%9,5 oranında katkı sağlıyorlar. Evli ve dulların katkı oranı ise \%3,80. İşverenler 144 paunddan fazla kazanıyorsa kazancı oranının \%11.9 'u. Devlet ise vergiler yoluyla katkı sağlar ve herhangi bir açık durumunda hazine açıkları kapatır.

Sigortalılar haftalık olarak 146 paund ile 817 paund arasında yararlanırken, esnaflar en az 5.595 paund un altında olmayacak şekilde beyan ettikleri gelirleri oraninda faydalanirlar (SSA, 2012).

\subsection{Hollanda}

Karma sistem özünde hem Bismark Sistemini hem de Beveridge sistemini barındıran bir sosyal güvenlik sistemidir. Bu sistemde sosyal güvenliğin finansmanı işçiler için işverenleri tarafından ücretlerin belirli bir yüzdesi tarafından sağlanmakta, 15-65 yaş arası halk maktu prim ödemekte, belirlenen yaş sınırının altında ve üstünde kalanlar ise primden muaf tutulmaktadır. Tahsilat görevi vergi dairelerine verilmiştir. İş görmezlik doğuran ve tedaviyi gerektiren durumlar için hastalık kasaları faaliyette bulunmaktadır. Yaşlılık ve ölüm riskleri için sosyal güvenlik bankası hizmet vermektedir (SGK, 2012: 176).

Hollanda Krallığı'nda ikamet eden herkes (işçi, kendi adına ve hesabına bağımsız çalışanlar, işsizler...) ulusal sigorta programı kapsamında 
(volksverzekeringen) yaşlılık, malullük, uzun süreli iş göremezlik, çocuk yardımı ve temel sağlık hizmetleri gibi sigorta kolları açısından sigortalı sayılmaktadır. Bununla birlikte çalışanlar; hastalık, iş göremezlik ve işsizlik sigortaları bakımından sigortalanmaktadir.

Hollanda'da emeklilik sistemi üç sütunlu bir yapı olarak tasarlanmıştır. Bu sütunlu yapı şu şekildedir:

- Zorunlu devlet emeklilik sistemi (birinci sütun)

- İşverenlerin sorumluluğundaki gönüllü mesleki emeklilik sistemi (ikinci sütun)

- Gönüllü özel emeklilik sistemi (üçüncü sütun)

Hollanda'da yaşlılık sigortası kapsamında sağlanan emeklilik aylı̆̆ından faydalanmak için ikamet esaslı bir sistem vardır. 15 ile 65 yaş arasında kesintili veya sürekli olarak Hollanda Krallığı'nda ikamet etmek, emeklilik aylığından faydalanmak için yeterlidir. Ancak 15 ile 65 yaşları arasında kişi gelir getiren bir faaliyete sahip ise prim ödemek zorundadır. İkamet edilen her bir yıl \%2 ile çarpılıp 65 yaşına ulaşıldığında, toplam emeklilik aylığının yüzde kaçı oranında ödeme alınacağı bulunmaktadır. Prim miktarı; hizmet akdiyle çalışanlar, kendi adına ve hesabına bağımsız çalışanlar ve diğer vergi mükellefleri için vergilendirilebilir gelirlerin \%17,9'udur. Bu primler ister çalışsın ister çalışmasın (emekli) tüm yerleşikler tarafından doğrudan (ücretler üzerinden) veya dolaylı olarak (vergilerle) ödenmektedir. Prime tabi azami yıllık kazanç 32.738 avrodur. Devlet, alınan aylığı belirli durumlarda sosyal asgari geçim düzeyine yükseltmekte, öğrenci ve çocukluktan beri özürlü olanların primlerini ödeyerek destek vermektedir. Ayrıca, devlet yıllık olarak yaşlılık sigortası fonuna katkı yapmaktadır. Emeklilik aylığı evlenmemiş bir kişi için 1.017,97 avrodur. Evli olan veya evli olmaksızın birlikte yaşayan çiftler, eğer 65 yaşından büyük iseler kişi başına 698,58 avroluk bir aylık ödemesi almaktadır. Eğer kişi eşini kaybetmiş ve 18 yaşından küçük bir çocuk sahibi ise aylık 1289,67 avro almaktadır (SGK, 2012: 177).

Hollanda hükümeti 20 Şubat'ta fon yetersizliği yaşayan emeklilik fonlarına iyileşme süresini 3 ila 5 yıl arası bir süreci kapsayacak şekilde uzatmıştır. Mevzuata göre yetersiz fonlarla ilgili olarak, söz konusu fonların finansal dengesini sağlamakla görevli olan De Nederlandsche Bank (DNB) hızla düşmekte olan fon oranlarını asgari ortalama \%105 olarak saptamıştır. 2007 yılı sonunda bu oran ortalama \%144 olmuştur (SGK, 2012: 178).

\subsection{Yunanistan}

Hizmet akdine tabi olarak çalışmakta olanlar ve tarım dışı çalışan serbest meslek sahipleri sosyal güvenlik kapsamındadır. Kamuya ya da herhangi bir mesleki fona ait bir sandığa tabi olanlar; tarım işçileri, kamu işçileri, doktorlar, dişçiler, mimarlar, noterler, ticari motorlu araç operatörleri, gemi acenteleri, esnaf ve sanatkârlar sistem dışıdır. İsteğe bağlı sigortalılık mümkündür. Serbest kazancı olanların brüt aylık kazancından \%6,67'si, ağır işlerde çalışıyorlarsa \%8,87'si oranında; 
işverenlerden, yapılmakta olan işin ağırlığına göre \%13,33 veya \%14,73 oranında; devletten \%10 oranında yıllık prim kesilmektedir (Featherstone, 2005: 145).

1980'lerin başında sosyal harcamaların GSMH'ye oranı \%17 olan Yunanistan, topluluk üyesi ülkelerin bir hayli gerisindeydi. 1990'ların başına gelindiğinde Yunanistan Avrupalı ortaklarına yetişmek zorundaydı ve bu çerçevede sosyal harcamalar artırılması yönünde uygulamalar yapıldı. Bu çerçevede 1993 yılında, sosyal harcamaların GSMH'ye oranı \% 29'a yükseldi. Ancak sosyal harcamalardaki bu istisnai artış ekonominin kapasitesini aşıp uzun dönem mali sürdürülebilirliği konusunda endişelere sebep oldu (Garrett ve Mitchell, 2001: 35).

Ancak, Yunanistan'da 1990'lı yılların başında meydana gelen şiddetli ekonomik kriz ve politik belirsizlik ortamı sosyal harcamaların kısılması yönünde reformu kaçınılmaz hale getirdi. İlk reform inisiyatifleri Muhafazakâr Parti'den geldi. Reformun gerekçesi sisteme yeni bir düzenin temel özellikleri oluşana dek nefes alacak bir alan oluştururken emekli maaşlarının artan maliyetini (GSMH'nin \% 15'ine eşit ve tüm bütçe açığının neredeyse yarısı) kısıtlama ve makroekonomik düzenlemeleri destekleme temeline kuruldu (Carrera, 2009).

Yunanistan'da sosyal güvenlik sisteminde yapılan reformların ilk aşamasını 1990 yılında hükümetin açılamış olduğu geniş kapsamlı bir reform paketi oluşturmaktadır. Ana hatları, primlerde artış, memurlar için primlerin başlaması, maluliyet maaşına hak kazanma şartlarının sıkılaştırılması, emekli olma yaşını arttırma ve emekli maaşının hesaplanmasında değişikliklerdi. Ancak bu yasa ciddi bir muhalefetle karşılaştı.

İkinci kayda değer reform ise 1992'de gerçekleştirildi. Reformdan önce gelişen olaylar (hükümet komisyon komitesinin acelece hazırlanmakla gözden düşmesi, işçi sendikalarının hükümeti raporu gerçekleri gizleyen bir duman perdesi olarak kullanmakla suçlaması, kamu emekli maaşı harcamalarındaki demografik yaşlanmanın -reform gerçekleşmezse- 2050 itibariyle GSYİH'nın \%34,2'sine tırmanmasının yıkıcı etkisine dikkat çeken IMF komisyonu raporunun basına sızdırılması) kısa zamanda kamu sektörü çalışanlarından devlet bankalarında çalışanlara, taşıma sektörüne ve kamu kuruluşlarına sıçrayan bir dizi grevle doruğa çıktı. Hassas bir parlamenter çoğunluğa sahip hükümet bazı parti üyelerin belli koşullara karşı çıkmasıyla daha da sıkıntıya düştü (Garrett vd, 2001: 56).

1992 yasasında hükümet 1990'dan dersini alarak düzenlemelerden kaynaklanacak sıkıntıların çoğundan sendika üyelerini koruyarak ve yükü gelecek nesillerin üzerine yıkarak sendikalarla karşı karşıya gelmekten kaçındılar. Buna göre reform, daha yüksek prim katkısı ve çalışırken ele geçen ücrete göre daha düşük emeklilik geliri oranları (\% 60'a karşılık \% 80) getirirken hem erkekler için ve hem de kadınlar için emeklilik yaşını 65 olarak belirledi. 1996 yılında Avrupa Para Birliği'ne giriş hükümetin en önemli amacı haline gelmiş ve asgari emekli maaşı alanlar için gelire bağlı yardım yürürlüğe konmuştur. Bunun yanında sosyal sigorta mini reformu kanunlaştırılmış ve evde bakım pilot programı genişletilirken Ulusal Sosyal Bakım Örgütü kurulmuştur. 1998 yılında ise göçmen işçiler yasallaştırılmıştır. 
1990'ların sonuna gelindiğinde, Ekonomi Politikası Komitesi'nin (Economic Policy Committe - EPC) yaşlanan nüfusların kamu maliyesinin uzun dönem sürdürülebilirliği üzerinde etkisi hakkında özellikle Yunanistan'daki, kamu emeklilik giderlerinin GSMH'ye oranının 2000'de \% 12,6'dan 2050'de \% 24,8'e çıkacağı, yaşlı bağımlılık oranının 2050 itibariyle \% 54'e yükseleceği (2000'le karşılaştırılırsa \% 26), ve bunun AB-15 arasında en yüksek ikinci olduğu ve bu sebeple giderlerde ciddi bir artışa yol açacağ1 yönünde öngörüleri olmuştur. Bundan dolayı, 2001 yılında yapılan başarısız reformun ardından 2002 reformu, uygunluk, mali sürdürülebilirlik ve modernizasyon hedeflerine erişmeye katkı sağlayan masrafları kısacak önlemler olarak tanımlandı. 2004 seçimleri sonrasında ise Muhafazakar Parti'nin iş başına gelmesiyle sosyal diyalog süreci başlatıldı. Her ne kadar Yunan Parlamentosunda devam eden sosyal diyalogla ilgili şüpheler ortaya çıksa da, Mart 2008 sonunda sosyal güvenlik sisteminde reform onaylandı. 2008 yasası iki kısımdan oluşmaktadır. İlki teşkilat yapısı ve yönetim ile ilgilidir. İkinci kısım ise emeklilik programlarının (scheme) toplam sayısını 155'ten 13'e indirip üst limit olarak belirleyen fonları birleştirecek zorunlu önlemleri içeren spesifik fonların rasyonalize edilmesini hedefliyordu (Fultz ve Ruck, 2011:57).

2008 yılında patlak veren küresel ekonomik kriz ve bu krizin Avrupa'da borç krizine dönüşmesi, Yunanistan'da sosyal güvenlik sisteminde reform çalışmalarının yeniden tartışılmasına neden olmuştur (SGK, 2012:178).

2010'da, Yunan Parlamentosu, AB ve IMF ile 145 milyar ABD Doları tutarındaki anlaşmanın kilit unsurlarından biri olan ulusal emeklilik sistemindeki önemli değişiklikleri onaylamıştır. Reformlarla, emeklilik yaşı ve katkı yılı yükseltilmekte, kazançla ilişkili emekli ödenekleri azaltılmaktadır. Aynı zamanda ödenseğe tahakkuk eden vergi oranları arttırılırken erken emeklilik azaltılmaktadır. Bu sıkı reformla 2050 yılına kadar yıllık emeklilik harcamalarının GSYİH içindeki payının \%8,5'e kadar düşürülebilmesi hedeflenmektedir (Sarfati ve Ghellab, 2012: 69).

\section{5. İspanya}

Güney Avrupa refah rejiminin tipik özelliklerine sahip olarak İspanya'da yerleşik tüm çalışanlar ve işverenler ücret geliri üzerinden sosyal güvenlik sistemine aylık olarak prim katkısında bulunmak zorundadır. Prim katkısı genel olabileceği gibi, tarım işçileri, deniz adamları, hizmet-çiler için özel sosyal güvenlik sistemleri de olabilir. Söz konusu zorunlu prim ödemeleri bireysel gelir vergisi tespitinde matrahtan indirilebilmektedir (IBFD, 2009:766).

İspanyol zorunlu sosyal güvenlik sistemi, diğer $\mathrm{AB}$ ülkelerinde olduğu gibi "Pay As You Go" ilkesi yani konumuz açısından "önce öde sonra yararlan" diye ifade edilebilen prim sistemi ile finanse edilmektedir. Tüm sigorta kollarını kapsayan prim katkısı sistemi yerine, birçoğunu kapsayan bir prim sistemi bulunmaktadır (Sarfati ve Ghellab, 2012: 89).

Sosyal güvenlik hizmetlerinin finansmanı amacıyla tahsil edilen genel katkı payının işçi ve işverenler arasında dengeli dağılmadığı görülmektedir. Genel katkı 
payı çalışanlar için \% 4,7 iken, işverenler için \% 23,6'dır. İşverenler ayrıca iş kazası sigortası içinde prim ödemek zorundadır. Prim oranı ise işin niteliğine göre değişmektedir. İşsizlik sigortası primleri de benzer şekilde daha yüksek oranda işverenlerden tahsil edilmektedir. Çalışanlar açısından \% 1,55 olan işsizlik sigortası primi işverenler açısından \% 5,5'dir. Bunların dışında işverenlerden maaş garanti fonu ve mesleki eğitim amacıyla \% 0,8 katkı sağlanmaktadır. Sosyal güvenlik hizmetleri, çalışan ve işverenlerin prim katkılarının yanı sıra devlet bütçesinden yapılan transferler, yani vergiler ile de finanse edilmektedir (MISSOC, 2015).

İspanyol sosyal güvenlik sistemi çerçevesinde ayni sağlık yardımları ile aile ve çocuk yardımlarının vergiler yoluyla finanse edildiği görülmektedir. Sağlık ve analık yardımları (nakit olanlar), sakatlık, yaşlılık, dul ve yetim yardımları, iş kazaları ve mesleki hastalıklar ve işsizlik ile ilgili ödenek ve yardımlar ise prim katkıları ile finanse edilmektedir. Yaşlı ve engellilere yönelik uzun süreli bakım hizmetleri ise yerel kuruluşlar ve yararlanıcıların desteğiyle devlet ve özerk kuruluşlar eliyle sunulmaktadır (Çiçek, 2015).

Tarihsel süreçte İspanya, AB'ye üyelik sürecinin başladığ1 1975 yılına kadar siyasi, ekonomik ve sosyal yapısında istikrarsızlık yaratan birçok koşuldan olumsuz etkilenmiştir. 1990 yıllarda sosyo-ekonomik değişimler neticesinde emeklilik sisteminin sürdürebilirliği ile ilgili tartışmalar artmış, reform gereklilik olarak görülmeye başlamıştır. 1995'ten sonra Toledo Paktı ile primli ödemeler azaltılıp, primsiz yardımlar arttırılarak bir değişim sağlanmıştır (Parlak, 2016). Ancak 2008 krizinden etkilenerek Avrupa'nın ciddi olumsuzluklarla karşı karşıya kalmış ülkelerinden biri olmuştur. Bu dönem sonrasında ekonomik büyüme gerilemiştir. GSYİH'de büyüme 2006'da 4.7 iken 2008 sonrasında eksi seviyelere düşmüştür. Var olan işsizlik problemi ise, bu azalma ve istihdamda daralma ile birlikte daha da artmıştır. Bu olumsuz sonuçlarla birlikte demografik geçişler ve sunulan cömert yardımlar, dağıtım yöntemi ile tanımlı fayda kamu emeklilik sisteminin finansal olarak sürdürülemezliğine yönelik endişeleri ortaya çıkarmış kamu maliyesini ve emek piyasasını önemli ölçüde etkilemiştir (Carrera vd., 2009). Bu durum, 2001 ve 2006 yıllarında reformları getirmiş, diğer önlemlerle beraber emekli sisteminin iyileştirilmesi sağlanmaya çalışılmıştır.

İspanya'da reformlarla, kazanç ve emeklilik ödeneği arasındaki bağlantının güçlendirilmesi hedeflenmiştir. Emeklilik yaşı ertelenerek "yaşam ömrüne otomatik ayarlama" ilkesi getirilmiştir. Diğer taraftan katkı payı artırılırken emekli ödeneği değerinin düşürüldüğü görülmektedir (Sarfati ve Ghellab, 2012: 79).

Her ne kadar tasarruf önlemleri ve kemer sıkma politikalarıyla bütçe açı̆̆ azaltılmaya çalışılmaktaysa da, İspanya'da demografik, ekonomik ve siyasi riskleri karşısında emeklilik sisteminin yeniden yapılanması ve yaşam standardının korunması için tamamlayıcı bir emeklilik planının geliştirilmesi gerektiği anlaşılmaktadır (Gim'enez ve D'iaz-Saavedra, 2016). 


\subsection{Türkiye}

Türk sosyal güvenlik sisteminde, hizmet sunumu primli ve primsiz olmak üzere iki farklı yöntem kullanılmaktadır. Primli yöntem genellikle sosyal sigorta esaslarına göre düzenlenmiş, bireylerin karşılaştığı risklerin azaltılmasında ve ekonomik güvenliklerinin artırılmasında devletin sosyal güvenlik sistemi kurup yönetmesine dayanan, primli katkıya dayalı dağıtım yöntemidir. Primsiz yöntem ise kimsesiz, muhtaç, yaşlı, engelli, dul, yetim ve korunmaya muhtaç çocuklara karşılıksız verilen ve genel olarak bütçesi merkezi bütçe, belediye, vakıf ve gönüllü kuruluşlar yoluyla karşılanan katkısız yöntemdir (Yılmaz, 2006: 94).

İkinci Dünya Savaşı'nın akabinde hayata geçirilen Türkiye'nin resmi sosyal güvenlik sistemi, Güney Avrupa'da gözlendiği gibi katmanlı ve eşitsiz bir destek kurgusu ile korporatist nitelikteydi. Özünde bu sistem, memurlara ve işçilere yaşlılık ve sağlık destekleri sunmaktaydı. Sistem şekillendikçe üçüncü bir sosyal güvenlik örgütü olarak kurulan Bağ-Kur, serbest meslek sahiplerini ve çiftçileri sisteme kattı (Buğra, 2008:157).

1990'larda nüfusun yüzde sekseninden çok daha fazlası ya prim ödeyerek, ya da bunların bakmakla yükümlü oldukları kişiler olarak sosyal güvenliğin kapsamı altındaydı. Fakat sosyal güvenlik sistemi, her üç kurumun kapsamındaki kişilere yönelik emeklilik ve sağlık katkılarındaki önemli dengesizlikler sonucu büyük ölçüde eşitsizdi. Sosyal güvenlik sisteminin bu eşitsiz korporatist niteliği sonucunda, sağlık hizmetlerine erişim birçokları, özellikle de zaman zaman primlerini ödeyemeyip, haklarından mahrum kalan serbest çalışanlar için sorunlu hale geliyordu. Ekonomik kriz dönemlerinde bu sorun çok daha ciddileşebiliyordu. Memurlarınkiler dişında, emeklilik maaşları da hak sahiplerine nezih bir yaşam sağlamaktan uzak bir düzeyde kaldı. Birçok insan, yaşlılığında mahrumiyet yaşamamak için aile destek mekanizmalarına dayanmak zorundaydı.

1976 yılına kadar Türkiye'de sosyal yardımlar gönüllülük esasına göre işlemekteydi. Gönüllülük esasına dayanan sosyal yardım faaliyetleri yoksulluğu yapısal bir sorun olarak kavramaktan uzak, devamlılığı açısından riskli ve ulaşılabilirliği açısından yetersizdi (Metin, 2011: 185-186).

Türkiye'de ES, SSK ve Bağ-Kur devlet tarafından kurulmuş; fakat birbirlerinden bağımsız ve teorik olarak devletten de özerk kurumlardı. 1980'lerden sonra bu kurumların harcamaları topladıkları primlere oranla arttı; ayrıca kaynaklarını kötü değerlendirdikleri için harcamalarını karşılayamaz duruma geldiler ve devlet bütçesinden desteklenmeleri gerekti.

Türk Sosyal Güvenlik Sisteminin yaşadığı kriz, özellikle siyasi iktidarlar tarafından, ağırlıklı olarak finansman boyutuyla ele alınmış ve sosyal sigorta kurumlarının bütçe üzerine yük oluşturmayacak bir "gelir-gider dengesine" kavuşturulmalarına yönelik tedbirler ve düzenlemeler, yapılacak sosyal güvenlik reformunun önemli unsurları olarak kabul edilmiştir. Nitekim 4447 sayılı Kanun'da, bu 
görüşün bir yansıması olarak gündeme gelmiştir ve bu nitelikteki değişiklikleri ihtiva etmektedir (Alper, 1999: 1).

Türkiye Cumhuriyeti ile Dünya Bankası arasında 1994 yılında imzalanan kredi anlaşması sonucu 25.8.1999 tarih ve 4447 sayılı Kanun ortaya çıkmıştır. Bu Kanun ile biri "İşsizlik Sigortası Kanunu" adını taşıyan, beşi sosyal güvenlikle ilgili kanunlarda ve biri de İş Kanunu olmak üzere toplam yedi kanunda önemli düzenlemeler ve değişiklikler yapılmıştır. Bu Kanun'un getirdiği düzenleme ile Türkiye'de sosyal gelirlerin, daha açı deyişle yaşlılık, malullük ve ölüm aylıklarının gerek ilk bağlanış, gerekse işleyişleri sırasında değişen iktisadi şartlara uyumu, sağlanması bakımından tam dinamik bir sisteme geçilmesi düşünülmüştür. Gerek yaş, gerek emekli aylıklarının hesaplanması, gerek sosyal güvenlik destek primi, sağlık yardımlarından yararlanma primlerinin tahsilinde gecikme zammı uygulanması gibi belirli konularda farklı sosyal güvenlik kurumları arasında sınırlı da olsa bir standartlaşma sağlanmış olmaktadir (Tuncay, 2000: 5).

En son olarak, Türk sosyal güvenlik sisteminin 'tek çatı' altında toplanması yönünde, "Sosyal Güvenlik Sisteminde Reform" kapsamında, kurumsal yapıda teklik esasını gerçekleştirmek amacıyla, 16.03.2006 tarih ve 5502 sayılı Sosyal Güvenlik Kurumu Kanunu yürürlüğe konulmuş ve bu Kanunla Sosyal Sigortalar Kurumu, T.C. Emekli Sandığı ve Bağ-Kur'un tüzel kişilikleri sona erdirilerek (m.43), tek kurum olarak, "Sosyal Güvenlik Kurumu" adı altında toplanılmıştır. Sosyal güvenlik haklarının tek yasa içinde düzenlenmesi amacıyla da 31.05.2006 tarih ve 5510 sayılı "Sosyal Sigortalar ve Genel Sağlık Sigortası Kanunu" çıkarılmıştır. Bu Kanun, işçi, memur ve bağımsız çalışanların sosyal sigorta haklarını tek metin içinde düzenlemekte (m.2 vd.) ayrıca genel sağlık sigortasını öngörmektedir (m.60 vd.).

Genel sağlık sigortası, sağlık hizmeti alacak kişilerden prim toplanması esasına dayanan bir sistemdir. Hane içerisindeki kişi başına düşen aylık geliri asgari ücretin üçte birinden fazla olan tüm vatandaşlar her ay prim ödemek zorundadır. Ancak asgari ücretin üçte birinden daha az geliri olduğunu belgeleyen kişilerin primleri devlet tarafından ödenmekte ve sağlık hizmetlerinden ücretsiz olarak yararlanmaları sağlanmaktadır. Prim ödemekle yükümlü bulunan kişiler prim borçlarını ödememeleri halinde sağlık hizmetlerinden yararlanamamaktadırlar. Bu bağlamda genel sağlık sigortası sistemi vergilerle finanse edilme ilkesine dayanmadığı için kapsamının evrensel olduğundan söz edilememektedir. Prim borcu bulunanlar genel sağlık sigortasından yararlanamamakta ve sağlık hizmetlerine erişememektedirler (Kol, 2014:156).

\section{SONUÇ}

Ekonomik ve sosyal sorunlara ek olarak nüfusun yaşlanması ve doğurganlık oranının düşmesi ile ortaya çıan demografik değişim tüm dünyada refah devletlerini krize sürüklemiş ve sosyal güvenlik sistemlerinde reform yapılması kaçınılmaz bir hal almıştır. 
Sosyal güvenlikte reform arayışlarının temel nedenlerinden birisi sosyal güvenliğin içerisinde bulunduğu finansman krizidir. Söz konusu krizin ilk olarak Amerika, Fransa ve Belçika gibi gelişmiş ülkelerde ortaya çıııp daha sonra Hollanda, Norveç ve İsrail gibi ülkelerde yaygınlık kazanması sorunun ağırlığı açısından büyük bir anlam ifade etmektedir. Refah devletinin kriziyle başlayan sosyal güvenlikte reform çalışmaları, 1980'li yıllardan itibaren hız kazanmış ve alternatif çözüm önerileri geliştirilmeye çalışılmaktadır. Krizden çıkış amacıyla ülkeler tarafından benimsenen yeni anlayışlar ve uygulamaya konan tedbirler şunlardır:

- Sistemin daha etkin ve ekonomik olarak düzenlenmesine önem verilmektedir,

- Toplumun en çok ihtiyaç duyan kesimlerine hizmet götürülmesi amaçlanmaktadir,

- Genelleştirilmiş ve sosyal güvenlik yardımları yerine, kişisel ihtiyaçlar ve farklılıklar dikkate alınmaktadır,

- Sosyal güvenlik sistemlerinin popülist uygulamaların dışında tutulmasına ve hükümetlerin sosyal güvenlik fonlarına müdahale etmemesine özen gösterilmektedir. Sosyal güvenlik kuruluşlarının özerk ve bağımsız bir statüye kavuşturulmasına önem verilmektedir,

- Sanayileşmiş ülkelerde 1970'li, 1980'li yıllarda işsizliğe karşı bir alternatif olarak uygulanan erken emeklilik politikaları, sistemin mali yükünü arttırmıştır,

- Ülkeler bu uygulamayı terk ederek emeklilik yaşını yükseltmekte, hak kazanma koşullarını zorlaştırmakta, sağlanan yardımları azaltmaktadırlar.

Akademik tartışmalarda Esping-Andersen'in refah devleti modelinde politikaların daha etkin şekilde yürütülmesini sağlayacak reformların istenilen ölçüde gerçekleştirilemediği ifade edilmektedir. Ancak, özellikle Almanya örneğinde istihdam piyasalarında, emeklilik ve bakım sigortası gibi birçok alanda yapılan reformların sonuçları olumlu şekilde alınmaya başlanmıştır. Kıta Avrupası sosyal refah devleti modelinin en önemli temsilcisi olması ve dünyadaki sosyal devletlerin en büyükleri arasında yer alması kuşkusuz sosyal devletin geleceği ile ilgili tartışmalar ve reformların Almanya üzerindeki etkilerinin takip edilmesi açısından önem arz etmektedir. Ülke ekonomisinin büyümeyi sürdürmesi ve son 10 yılda yürürlüğe konulan çeşitli reformlar bazı sıkıntılarına rağmen, sosyal devlet uygulamalarının sürdürülebilir olduğunu göstermektedir (Kol, 2014: 20).

Güney Avrupa ülkelerinde, özellikle Yunanistan'da reformların hızlı ve erken uygulanmadığ1 görülmektedir. 2008 ekonomik kriziyle kötü yönetilen emeklilik sistemiyle ekonomik kriz birleştiğinde acı reçetelerle bu durumu iyileştirmenin o kadar kolay olmadığı görülmüştür. Güney Avrupa refah modeline sahip ülkelerin finansman krizine girmelerinin temel nedenleri arasında, sosyal harcamaların artmasının yanısıra mali sorumsuzluklarının da olmasıdır. Bu sıkıntıların gelecekte de devam edeceği ve yaşlanmanın yönetilen bir olgu olduğundan hareketle ülkelerin sosyo-ekonomik faktörlerine ve geleneklerine uygun çözümler oluşturması oldukça önemlidir.

Güney Avrupa ülkeleri aralarındaki farklılığa rağmen, demografik gerçekler, ekonomik büyüme, sosyal güvenlik sistemlerinin kurumsal eksikliği gibi benzer 
sorunlarla karşı karşıyadır. Güney Avrupa Refah Modeli'ne sahip ülkelerin kamu harcamaları hâlen Muhafazakâr ve Sosyal Demokrat Refah Modeli'ne sahip ülkelerin kamu harcamalarından daha az, Liberal Refah Modeli'ne sahip ülkelerin ise üzerindedir. Esasında, Güney Avrupa Refah Modeli'ne sahip ülkelerin kamu harcamalarının fazla olması görünürde sorun teşkil etmese de kamu gelirlerinin düşük olmasından dolayı iktisadi açıdan sağlıklı görünmemektedir. Zira bu ülkelerin harcamaları gelirlerinden çok olduğundan devletin büyüklüğü ya da küçüklüğünün yanında ne kadar verimli oldukları sorununu da beraberinde getirmektedir (Parlak, 2016:136).

$\mathrm{Bu}$ refah sistemleri içinde Türkiye'nin yerinin belirlenmesi ayrıca önem arz etmektedir. Çoğu çalışmalarda Türkiye, Güney Avrupa Sosyal Devlet Modeline dahil edilmektedir. Bunun sebebi, Türkiye'nin uyguladığı sosyal politikalar (sosyal yardım ve hizmetlerde dağınık, çok parçalı, aile merkezli yapı gibi) açısından söz konusu model ülkelerine benzerlik göstermesidir. Bunun yanı sıra, Türkiye'nin, bu modele giren Portekiz, İspanya ve Yunanistan gibi ülkelere yakın sosyo-ekonomik yapısının bulunması ve krize yatkınlığı, bu ülkeler gibi Türkiye'nin de diğer Batılı Avrupa ülkelerine nazaran daha geç modernleşme sürecine girmesi ve kayıt dışı ekonominin kontrol altına alınamaması gibi benzer sosyo-ekonomik sorunları bulunmaktadır. Bu benzer sorunlar, Türkiye'nin Güney Avrupa ülkelerinin tecrübelerinden yararlanabileceğini göstermektedir.

Türkiye'nin refah rejimi Güney Avrupa modeline yakın özellikler sergilemektedir. Bu özellikler arasında ailenin ve dini kurumların sosyal yardım ve sosyal hizmetler alanındaki etkinliği, kayıt dışı ekonominin büyüklüğü, tarım sektöründe çalışanların yoğunluğu belirtilebilir. Bununla birlikte Güney Avrupa ülkeleri vergilerle finanse edilmekte olan sağlık hizmetlerine ulaşmışken, Türkiye'de genel sağlık sigortası ile tüm vatandaşların sağlık güvencesine kavuşması ancak prim ödeme koşulunun yerine getirilmesi ile mümkün olabilmektedir. Bu bağlamda genel sağlık sigortası sistemi vergilerle finanse edilme ilkesine dayanmadığı için kapsamının evrensel olduğundan söz edilememektedir. Prim borcu bulunanlar genel sağlık sigortasından yararlanamamakta ve sağlik hizmetlerine erişememektedirler. Oysa ki, Tüm Avrupa ülkelerinde sağlı hizmetlerinin kapsamı evrensel olarak düşünülmektedir.

5510 sayılı Kanunla kademeli bir artışla 2036 yılından itibaren emekli olma yaşı 65'e yükseltilmesi ve kadın-erkek emeklilik yaşının eşitlenmesi kabul edilmiştir. Tamamlanması gereken prim ödeme gün ise, 4/a lılar için 7200 gün ve 4/b ve 4/c çalışanlar için 9000 gün olmuştur. Bu sistemle erken emekliliğin önüne geçilerek daha fazla çalışma ve sigortalıların daha fazla sistemde kalması amaçlanmaktadır (Gökbayrak, 2010: 186). Bu durumda, çalışma süreleri uzadıkça ödenek seviyelerinde düşüş ve gelir eşitsizliği belirginleşecektir.

Güney Avrupa ülkelerinde ve Türkiye'de kamu harcamalarının ve bütçe açıklarının artması sosyal güvenlik sistemlerinin aktüeryal dengelerini altüst etmiştir. Bu durum emeklilik sistemlerini uzun dönemde sürdürülebilmesini zorlaştırmıştır. Bu 
çerçevede yapılan reformlarla tüm ülkelerde emeklilik yaşı yükseltilirken emeklilik için gerekli prim gün sayısı ise arttırılmıştır. Bu şartlarda emekli olabilenlerin de, emekli olduklarında gelirlerinin yetersiz olacağı ve refah düzeylerinin düşeceği aşikârdır. Sonuç olarak diğer Güney Avrupa ülkelerinde olduğu gibi, Türkiye'de de sosyal güvenlik sistemine yönelik reformlarla, yaşlılıkta gelir seviyesinin düşeceği ve 30-40 yıl sonrasında yaşlı yoksullar yaratacağı açıktır.

\section{KAYNAKÇA}

Alper Y. (1999). "Sosyal Sigortaların Finansmanında Değişiklikler", Çimento İşverenleri Sendikası SSK.'da Yeniden Yapılanma Semineri, Antalya.

Alper, Y. (2011). "Sosyal Güvenlik Reformu ve Finansmanla İlgili Beklentiler", Sosyal Güvenlik Dergisi, Sayı: 1.

Arıcı Kadir, Türk Sosyal Güvenlik Hukuku, Gazi Yayınları, Ankara, 2015.

Binhan, E.Y. (2006). "Türk Sosyal Güvenlik Sistemi: Krizler ve Arayışlar" (Proje Koordinatör, Esfender Korkmaz), Sosyal Güvenlikte Yeni Yaklaşım: Bireysel Emeklilik, İstanbul: İstanbul Ticaret Odası Yayınları, Yayın No: 2006-21.

Bonoli, G. (1997). "Classifying Welfare States: a Two-dimension approach", Journal of Social Policy, Vol. 26, 1351-372.

Briggs, A. (2000). “The Welfare State in Historical Perspective”, C. Pierson ve F. G. Castles (Ed.). The Welfare State: A Reader içinde. USA: Blackwell Publishing, 16-29.

Budd, A. ve Campbell, N. (1998).;" The Role Of The Public And Private Sectors In The United Kingdom The Pension System"; Privatizing Social Security, 99-134.

Buğra, A. ve Keyder Ç.. (2006). "The Turkish Welfare Regime in Transition", Journal of European Social Policy, Vol. 16, No. 3, 211-228.

Buğra, A. (2008). Kapitalizm, Yoksulluk ve Sosyal Politika, İstanbul: İletişim Yayınları.

Carrera, L., M. Angelaki ve D. Carolo. (2009). "Structures, Political Competition And Societal Veto Players: The Politics", The 7th Annual Espanet Conference, The Future Of The Welfare State. Paths Of Policy Innovation Between Constaints And Opportunities, Urbino, Italy.

Çiçek, S. (2015). “Ücret Üzerindeki Mali Yükümlülüklerin İncelenmesi: İngiltere, Almanya, İspanya, Romanya", Hak-İş Uluslararası Emek Ve Toplum Dergisi, Cilt: 4, Yıl: 4, Sayı: 10.

D'iaz-Gim'enez, J. - D'iaz-Saavedra, J. (2016). The Future of Spanish Pensions. http://www.ugr.es/ julianalbertodiaz/research/PEN33-F12.pdf (Erişim Tarihi: 12/04/2014)

Esping-Andersen, G. (1990). The Three Worlds of Welfare Capitalism, UK: Polity Press.

Featherstone, K.(2005). “Soft Co-Ordination Meets Hard Politics: The European Union And Pension Reform İn Greece", Journal Of European Public Policy, Vol. 12 No: 4.

Ferrera, M. (1996). The "southern" model of welfare in social Europe. Journal of European Social Policy, 6(1), 17-37. 
Flora, P. ve Heidenheimer, A. J.. (1981). "The Historical Core and Changing Boundariesof the Welfare State", Flora, P. ve Heidenheimer, A. J. (Ed.). The Development of Welfare States in Europe and America içinde. New Jersey: The State University.

Fultz, E. ve Ruck, M. (2011). "Pension Reform in Central and Eastern Europe: Emerging Issues and Patterns", International Labour Review, Vol. 140, No. 1.

Garrett, G. ve Mitchell, D. (2001). “Globalization, Government Spending And Taxation In The Oecd", European Journal Of Political Research, Vol. 39.

Glennerster, H. (2000). British Social Policy Since 1945, Washington: Blackwell Publishers.

Gough, I. (2006)."Güney Avrupa'da Sosyal Yardım”, Ayşe Buğra ve Çağlar Keyder (Ed.). Sosyal Politika Yazıları. İstanbul: İletişim Yayınları, 231-260.

Gökbayrak, Ş. (2010). Refah Devletinin Dönüşümü ve Özel Emeklilik Programları, Ankara:Siyasal Kitabevi.

Gümüş, İ. ve Tatlıyer, M. (2013). “Güney Avrupa Refah Rejiminin Borç Krizi”, İş Ahlakı Dergisi, Sayı:6, 1-37.

Günay Cevdet İlhan, İş ve Sosyal Güvenlik Hukuku Dersleri, Yetkin Yayınları, Ankara, 2004.

Güzel, A., Okur A. Ve Caniklioğlu N. (2016). Sosyal Güvenlik Hukuku, İstanbul, Beta Yayınevi.

Hayek, F. (2000)., “The Meaning Of The Welfare State”, C. Pierson Ve F. G. Castles (Ed.). The Welfare State: A Reader İçinde., Cambridge: Blackwell Publishing.

Hedva, S. ve Ghellab, Y. (2012). The political economy of pension reforms in times of global crisis: State unilateralism or social dialogue?, ILO Working Paper No:37, Genava.

IBFD. European Tax Handbook 2009, (2009). Ed. Juhani KESTI, IBFD Global Tax Series.

Kol, E. (2014). “Refah Rejimleri Açısından Sağlık Sistemlerinin Değerlendirilmesi: Güney Avrupa Refah Modeli Ve Türkiye", Gümüşhane Üniversitesi Sosyal Bilimler Elektronik Dergisi, Sayı:10.

Koray, M. (2005). Avrupa Toplum Modeli, İkinci Baskı, Ankara: İmge Kitapevi Yayınları.

Korkusuz Refik ve Suat UĞUR, Sosyal Güvenlik Hukukuna Giriş, Ekin Yayınevi, Bursa, 2010.

Leibfried, S. (1993). "Towards a European Welfare State", New Perspectives on the Welfare State in Europe, (Ed.: C. Jones), London: Routledge Press, 133-143.

Luhmann, N. (2002). Refah Devletinin Siyaset Teorisi. (Medeni Beyaztaş Çev.), İstanbul: Bakış Yayınları.

Metin, O. (2011). "Sosyal Politika Açısından AKP Dönemi: Sosyal Yardım Alanında Yaşananlar", Çalışma ve Toplum Dergisi, 28, 179-200.

MISSOC Database, (2015). Comparative Tables on Social Protection, European Commission's Directorate-General for Employment, Social Affairs \& Inclusion.

OECD. (2010). “Tax Revenue Trends, 1965-2009”, OECD Revenue Statistics 2010, OECD Publishing.

Önder, M. (2012). Türkiye'de Kayıtdışı Ekonomi ve Uluslararası Uygulamalar Işığında Çözüm Önerileri, Yayımlanmamış Uzmanlık Tezi, Maliye Bakanlığı, Ankara. 
Özdemir, S. (2004), “Refah Devleti ve Üstlendiği Temel Görevler Üzerine Bir İnceleme”, ABTürkiye \& Endüstri İlişkileri, (Editör: A. Hekimler), İstanbul, Beta Yayınları, 589-639.

Özdemir, S. (2005), “Sosyal Gelişim Düzeyleri Farklı Refah Devletlerinin Sınıflandırılması Üzerine Bir İnceleme", Sosyal Siyaset Konferansları, (Prof. Dr. Turan Yazgan'a Armağan Özel Sayısı), Sayı: 49, İstanbul: İ.Ü. İktisat Fakültesi Yayını, 231-266.

Özdemir, S. (2007). Küreselleşme Sürecinde Refah Devleti, İstanbul: İTO, Yayın No: 2007-57.

Özmen, Z. (2015). Türk Sosyal Güvenlik Sisteminin Mali Krizi ve Çözüm Önerileri, Yayınlanmamış Doktora Tezi, İstanbul.

Parlak, N. (2016). "Güney Avrupa Rejiminde Emeklilik Sistemleri: Mukayeseli Bir Analiz", Kırklareli Üniversitesi İktisadi Ve İdari Bilimler Fakültesi Dergisi (Issn: 2146-3417) Cilt: 5 - Sayı: 1.

Pierson, C. (1998). Beyond the Welfare State: The New Political Economy of Welfare, 2nd ed., Pennsylvania: The Pennsylvania State University Press.

Saltman R., Busse R. ve Figueras J., (2004). Social Health Insurance Systems in Western Europe, Open University Press.

Seyidoğlu, H. (1999). Ekonomik Terimler Ansiklopedik Sözlük. İstanbul: Güzem Can Yayınları.

Sosyal Güvenlik Kurumu Başkanliği, (2012). Avrupa Birliği'nde Sosyal Güvenlik. Ankara.

Sözer, A. N. (1994). Türkiye'de Sosyal Hukuk, Ankara: Kamu-İş Yayınları.

Ssa, “Historical Background And Development Of Social Security” http://www.ssa.gov/history/briefhistory3.html (Erişim Tarihi: 10/12/2012)

Şakar, M. (2017). Sosyal Sigortalar Uygulaması, İstanbul, Beta Yayınevi.

Taşçı, F. (2013). "Refah Devleti Modelleri İçinde Türkiye'nin Pozisyonu: "Yaşlı Algısı" Üzerinden Değerlendirmeler", İnsan ve Toplum Dergisi, 3(5), 5-35.

Toprak, D. (2015). “Uygulamada Ortaya Çıkan Farklı Refah Devletleri Üzerine Bir İnceleme”, Süleyman Demirel Üniversitesi Sosyal Bilimler Enstitüsü Dergisi, Sayı:21, 151-175.

Titmuss, R. (1958). Essays on the Welfare State, London: Allen and Unwin Publications.

Tiyek, R. ve Yertüm, U. (2016). “Güney Avrupa Refah Rejimi Bağlamında Türkiye: Bir Değerlendirme", Kırklareli Üniversitesi İktisadi ve İdari Bilimler Fakültesi Dergisi, Say1:1, 26-51.

Tuncay, A. C. (2000). Genel Çizgileriyle 4447 sayılı Kanun, Çimento İşveren, Cilt: 14, sayı: 1, 5.

Tuncay, A.C. ve Ekmekçi, Ö. (2012). Sosyal Güvenlik Hukuku'nun Esasları, İstanbul: Beta Yayınevi, 15. Bası.

Wendt C., FrisinaL., ve Rothgang H., (2009). "Healthcare System Types: A Conceptual Framework for Comparison", Social Policy \& Administration, 43(1), 70-90.

Yılmaz, V. (2012). Türkiye'de sağllk sisteminin dönüşümü: Firsatlar ve tehditler. spmk.ku.edu.tr/sunumlar/yilmaz.ppt (Erişim Tarihi:10 Aralık 2016). 